\title{
Appropriations and Innovations in Metalinguistic Terminology in an Influential Telugu Grammar Composed IN SANSKRIT ${ }^{\star}$
}

\author{
Deven M. Patel \\ University of Pennsylvania, Philadelphia, USA
}

\section{Abstract}

The various traditions of Sanskrit grammar have served as models, or as sources for metalinguistic description, for many other grammars composed to describe South Asian classical or local literary languages. This article investigates the contents of the first chapter (on metalinguistic terms) of a remarkable and influential medieval grammar of the major Dravidian language Telugu, or Āndhrabhāsāā, known as the Ândhraśabdacintāmaṇi. This grammar was composed with the same technical precision and a style similar to that of Pānini's Asțādhyāyzi. Hence, the purpose of this article: to study the processes of adaptation of metalanguage and of the Sanskrit metalinguistic technologies to describe Telugu in Sanskrit, a language that has both profound lexical affinities and striking phonological and morphological divergences from Telugu.

\section{Keywords}

metalanguage, grammar, Pāṇini, Telugu, Sanskrit, Prakrit

\section{Résumé}

Les diverses traditions de grammaire sanskrite ont fourni des modèles, ou des sources de description métalinguistique, pour nombre de grammaires décrivant les langues littéraires classiques ou locales d'Asie du Sud. Cet article porte sur le contenu du premier chapitre (consacré aux termes métalinguistiques) d'une grammaire médiévale remarquable et influente de l'incontournable langue dravidienne télougoue (ou āndhra-bhāṣā), connue sous le nom de Ändhraśabdacintāmani. Cette grammaire fut composée avec la même précision technique et un style similaire à ceux de l'Astāadhyāȳ de Pān ini. D'où l'objet du présent article : étudier les processus d'adaptation de la métalangue et des technologies métalinguistiques sanskrites pour décrire le télougou en sanskrit, une langue qui présente à la fois des affinités lexicales profondes et des divergences phonologiques et morphologiques frappantes par rapport au télougou.

\section{Mots-clés}

métalangage, grammaire, Pāṇini, télougou, sanskrit, prakrit

\section{INTRODUCTION}

Referring to the celebrated Tamil grammar Tolkappiyam's absence of Pānini's specialized metalinguistic affix-symbols and symbol-clusters to designate the morphophonemic features of Sanskrit, A.C. Burnell muses that "indeed it is impossible to see what use [Pāninini's technical language] could be in a grammar of one of the so-called Dravidian languages" (Burnell 1976, p. 40). One may feasibly

^ I am grateful to Dr. Émilie Aussant for a careful reading and the many insightful suggestions. 
extend this question to query how the adoption of any metalanguage - technical or not-designed for one language significantly benefits the analysis of another language, especially for one that, on the surface, seems unsuited for that kind of analysis. Perhaps in a capacity akin to the actual method adopted to describe a language, a grammatical technical terminology is always tightly linked to a certain conception (more or less sophisticated) of language. Extending, therefore, the metalinguistic conventions from an established grammatical tradition too mechanically and over-projecting similarity between languages may have the unwanted consequence of imprecision, albeit in service of "learning" and teaching the language better in a multilingual or polyglossic context.

The choice of grammatical terms, as with the method of analysis, has the very important function of serving as a code of reference for users of a grammar and strategically facilitates access to extrinsic linguistic resources that inform the text. In a bilingual or diglossic situation, the adoption of grammatical terminology marked to express metalinguistic awareness has an even more pronounced function, namely to illuminate features of linguistic description that might otherwise remain irredeemably occluded or inadequately demonstrated for language learners. It is in these contexts, one might argue, that the text under discussion here - a grammar of Telugu composed entirely in Sanskrit - is illustrative.

For a grammar of Telugu to be composed in Sanskrit, appropriating metalanguage developed to describe Sanskrit, the two languages must have enough in common to make such an exercise possible. Indeed, Telugu shares with Sanskrit several important typological features. In addition to its wide sharing of base lexical forms, like Sanskrit, Telugu has a complex network of sandhi processes (morpho-phonological fusions and transformations within words and between word boundaries). Both languages are also highly inflected, although, unlike Sanskrit, the Telugu adjective is not inflected for number, gender, or case. Telugu also shares with Sanskrit phonological characteristics in the number of nasal sounds that condition consonants. Some notable differences include Telugu's morpho-syntactic features, such as gender agreement with the verb. The language also possesses no discrete feminine gender, as words are described in the grammars as either masculine or non-masculine (which includes feminine and neuter words). Also distinct from Sanskrit and Prakrit, insofar as the letters are concerned, Telugu has a number of sound units, including short diphthong vowels $e$ and $o$ which, in Sanskrit, are always considered long vowels.

These and numerous other relationships and divergences that exist between Telugu, Sanskrit, and Prakrit are described in fine detail in an early Telugu grammar composed entirely in Sanskrit. This work, most commonly referred to as the Āndhraśabdacintāmanii ("A treatise [lit. "a wish-fulfilling gem"] on Andhra speechforms"), is preserved in a single manuscript and printed edition that has been recently translated into English (Sundaram and Patel 2016, p. 1-120). The grammar deserves 
attention both as a daring creative project of contrastive grammar and as a complex experiment in bilingual mediation among learned users of Sanskrit and Prakrit who also perhaps knew literary Telugu, Tamil, or another Dravidian language such as Kannada or Malayalam. ${ }^{1}$ Telugu, a major language of Deccan India, has a literary past that extends to, at least, the eleventh century and claims the largest number of speakers of any Dravidian language. To be precise, Telugu is a South-Central Dravidian language that perhaps may have been the earliest language to split from protoDravidian (Andronov 2003, p. 492), perhaps two millennia before we have the first non-inscriptional literary work in Telugu, the Mahābhāratamu from poet-saint Nannaya Bhattu. Nannaya is also known as the traditional author of the $\bar{A} n d h r a s ́ a b d a c i n t a ̄ m a n i i ~(\bar{A} S C$ hereafter), although there are compelling arguments that it may have been actually composed as late as the seventeenth century by Elakuchi Balasaraswati (1590-1670), who has made available a reconstituted Sanskrit text and Telugu commentary (Sundaram and Patel 2016, p. v-vii). ${ }^{2}$

In the printed version with Balasaraswati's commentary, the anonymous editor has split eighty-two verses in the $\bar{a} r y \bar{a}$ meter that comprise the $\bar{A} \hat{S} C$ into two hundred and seventy four short sütras. ${ }^{3}$ While the authorship and chronology of the $\bar{A} \dot{S} C$ is obscure, we can be certain that this remarkable text, though not composed in Telugu, has powerfully influenced arguably the most influential Telugu grammar (written in Telugu) still in use today. That work, a nineteenth-century grammar called Bālavyākaranamu by Cinnayasūri directly cites or reforms many of the $\bar{A} \bar{S} C$ 's sütras. ${ }^{4}$ Composed not in Telugu, but rather in Sanskrit, the $\bar{A} S C$ uses an eclectic

1 There are other such examples of Kannada and Malayalam grammars composed in Sanskrit, the Karnātabhāșabhūsanam (12-13 ${ }^{\text {th }}$ century), a Sanskrit grammar of Kannada, and the Lìlätilakam, a Sanskrit grammar of the mediaeval literary language of Kerala. For a technical analysis of Pāninian features in the Lĩlātilakam's description of medieval-era Malayalam, see Aussant 2012, p. 87-101.

2 Nannaya is considered the first Telugu poet and author of the grand Mahäbhäratamu, a version of the first two and a half sections or parva-s of the Sanskrit Mahäbhärata. Because of its association with Nannaya, therefore, Telugu tradition offers a series of alternative names of the Andhraśabdacintāmani that are based on the name or epithets associated with the poet: Nannayabhațīyamu, Vāganuśāsanīyamu, Śabdānuśāsanīyamu, Prakriyākaumudi, Āndhrakaumudi, and Āndhravyākaranamu.

3 The āryā meter has 12 mātrās, or measures (or "mora"), in the first and third pādas or versequarters, $18 m \bar{a} t r a \bar{s}$ in the second $p \bar{a} d a$, and 15 mätrās in the fourth pāda.

4 In a recent article, H.S. Ananthanarayana (2017, p. 70-85) presents Cinnayasūri's various textual iterations for translating Pāninian methods to Telugu grammar. Although Ananthanarayana does identify the Ändhraśabdacintämani as an influential source for Cinnaya's work, he does not identify specific sites of borrowing nor the significance of these borrowings. For example, sūtras 1.37 and 1.38 of the $\bar{A} S C$, which introduce the technical terms parusa ("hard" unvoiced stops) and sarala ("soft" voiced stops) are reproduced in Telugu virtually verbatim in the Bālavyākaranamu. Cinnaya's identification of Telugu as a vikrti ("modification") and Sanskrit/Prakrit as prakrti ("original source"), which Ananthanarayana understands as a mistaken notion on the part of Cinnaya (p. 72), is also a clear borrowing from the $\bar{A} \bar{S} C$ 's understanding of the relationship between the three languages. 
mélange of pre-Pāṇinian, Pāṇinian, and post-Pāṇinian metalanguage and organizational logic, offering a dramatic example of bold experimentation meeting pragmatic purpose in the field of Indian grammar. Using both ubiquitous technical Sanskrit metalinguistic terms along with the specialized Pāninian symbol-based formal system, the $\bar{A} S C$ 's sūtras are organized into five chapters (pariccheda): metalinguistic terminology (samjñ̄a) ; euphonic coalescence (sandhi); $;^{5}$ nominal bases/verbal stems ending in vowels (ajanta); nominal bases/verbal stems ending in consonants (halanta); and verbal action $(k r i y \bar{a})$. This text's organization, as well as contents, bear striking resemblance to later reformulations of Pānini's Asțādhyāyi ("[Grammar in] Eight Chapters"), as will be discussed below.

\section{Metalinguistic Terminology IN the $\bar{A}$ NDHRAŚABDACINTĀMAṆI}

The first chapter of the $\bar{A} S C$ has the heading of samjñ̄a (lit. a "name"), which, in the context of grammar, may be translated as a linguistic terminology that frames a discussion about a given entity or concept or, more comprehensively, as technical term that facilitates the complete understanding of a given entity or concept. This linguistic terminology either takes the form of natural words meaningfully rerouted to refer to various aspects of syntax, morphology, and phonetics, or to artificial vocabulary rooted in conventionalized symbol-units created to promote convenience of grammatical description. One would expect that while the former could transit from the grammatical analysis of one language to another, the latter would be restricted in jurisdiction to the source language. Therefore, it is unsurprising that certain words found across grammars of South Asian languages, etymologically comprehensible, like svara (vowel), vyañjana (consonant), avyaya (indeclinable) or anunāsika (nasal) occur ubiquitously before and after Pāninin's time in multiple linguistic contexts extrinsic to Sanskrit. However, Pāninini's technical language and symbol-clusters, appropriated to languages like Telugu without a hint of improbability, defies expectations. The fact that both types of technical terminologies are used by a work like the $\bar{A} \hat{S} C$ (not uniquely in South Asia) leads to reflection not only on the innovative exercise to extend metalinguistic terms by the later tradition but also on the powerful sway held by the metalinguistic technology in the first instance.

The $\bar{A} S ́ C$ employs both Pāninian symbols and their Telugu equivalents, in several cases shifting the significance of a Pāninian cluster (as in $a c$, 'vowel' in Pā nini's grammar, in $\bar{A} S C 1.18$, below) to manifest the specificity of Telugu forms. The author juxtaposes Pāninian technical language (eing [the diphthongs $e$ and $o$ ], aic [the diphthongs $a i$ and $a u$ ], hal [consonants], avyaya [undeclined forms], sup

5 Unlike Sanskrit, all sandhi in Telugu is marked by phonological loss occasioned by such coalescence (lopa-sandhi). 
[nominal forms], tin [verbal forms], ktva [gerund], tumun [infinitive]) and prePāṇinian terms (such as nāman [noun/nominal base], pratyaya [suffix], kriyā [verbal action], bindu [a "dot" that graphically represents nasalization]) alongside his own inventions, terms such as vakra (the diphthongs $e$ and o), vakratama (the diphthongs $a i$ and $a u$ ), prāṇi (consonants), varnaka (suffix), ${ }^{6}$ paruṣa ("hard" unvoiced stops), sarala ("soft" voiced stops), sthira (all other "stable" stops), and druta ("dissolution" of $n$ at the end of Telugu words). The term paruṣa ("hard"), for example, is used to identify unvoiced stops (alpa-prāna and aghoṣa are the corresponding Pāninian terms) while voiced stops are called sarala ("soft"); all other letters (aspirated, nasals, semi-vowels, and sibilants) are called sthira ("stable"). At other points, the author strategically juxtaposes Pāninian and prePāṇinian terms from Sanskrit sources - such as works on phonetics (prätiśăkhya) and etymology (nirukta) - that are also found in later works such as the Kätantra, a grammar tradition from the early centuries of the common era traditionally attributed to an author named Sarvavarman. With Pānini's sūtras arranged topically for perhaps the first time, the Kätantra introduces various new technical terms, which the $\bar{A} S$ C freely uses, as in 1.28 where the Kātantra technical term nāman ("name"), signifying a nominal base, is defined with the Pạninian corresponding term prātipadika. The $\bar{A} S C$ also clearly echoes a host of grammatical works that include analysis and rubrics of topical organization not found in the Aștādhyāy $\overline{\text {. }}$. Thus, for instance, the $\bar{A} S C$ in 1.14 follows Hemacandra's twelfth-century Siddhahemaśabdānuśāna in including a long vocalic $l$ while delineating vowels. ${ }^{7}$ The $\bar{A} S$ C similarly follows non-Pāninian rubrics for organizing content according to topic, first seen in the Kātantra but extending to Vararuci's canonical grammar on Prākrit Prākrtaprakāśa (probably from the third to fifth centuries CE) and Bhațtoji Dīkșita's popular early seventeenth-century Siddhāntakaumudī, among other works.

In India, grammars of Sanskrit have been the fountainhead for both methodology and terminology, and the process of language standardization - whether of classical languages, like Prakrit, or local languages from the regions - has taken recourse, in some measure, to the descriptive techniques or metalanguage developed by grammarians of Sanskrit. Thus, the Prākrtaprakāśa is composed in Sanskrit (as most Prakrit grammars are) and takes Sanskrit as the base language, extending Pạninian rules developed to describe Sanskrit to derive Prakrit languages.

6 The introduction of the technical term varnaka (sütra 1.29) is a distinct innovation of this grammar, referring to suffixes (such as the first-case nominal suffixes $-d u,-m u,-v u,-l u$ ) and equivalent to the Pāninian term pratyaya.

7 Hemacandra explains that Prākrit, has forty letters (Śabdānuśāsana 8.1), ten less than the fifty he identifies for Sanskrit (in Śabdānuśāsana 1.1.4): ṛl-varnau hrasva-dīrghā-vaijādyāvv anunāsikau śa-șā vete daśonās syuh prākṛtoktișu sarvathā. The ten missing letters are: r, r, $, 1, \overline{1}$, ai, au, ñ, ñ, śa, șa. 
Additional rules address those aspects in Prakrit that do not correspond with Sanskrit. The general logic of the Präkṛtaprakāśa structures the $\bar{A} S C$ as well. The typological proximity of both languages certainly facilitated the objectification of one language with the other language's descriptive terminology. Both languages have enough in common to justify such a move. In the case of the $\bar{A} S C$, the author places Sanskrit, Prakrit, and Telugu within the same linguistic and cultural domain. The substrata between these three languages should share morphological, structural, phonetic, semantic, lexical and, perhaps even psycholinguistic or cultural features in order to justify the experiment of tying the three together grammatically to promote bilingual pedagogy or, as may be the case, to perform a virtuosic gesture of unexpected comparativism to garner scholastic appreciation. The $\bar{A} S C$ frames the Telugu language not exactly as a Prakrit but also not necessarily as a distinctive language like Tamil. Rather it marks the boundaries of an identity as a language that is culturally equal to Sanskrit, derived from it, and wholly distinct from it. Each of these positions operates in discrete domains. The problems that might arise in the implementation of a developed metalanguage from the one grammatical tradition to another are not as salient, therefore, in the case of Sanskrit and Telugu as presented by this text.

What this suggests, as the author of the $\bar{A} \hat{S} C$ seems to presuppose in the following sütra, is that Sanskrit, Prakrit, and Telugu operate as structurally similar languages that vary in form. While Telugu word-forms that are derived from (or located in) Sanskrit and Prakrit forms (tadbhava) draw the three languages together, the presence of local speech-forms (deśya) leads the $\bar{A} S C$ to ambivalently label Telugu as a "distinctive modification," or vikrti, of Sanskrit and Prakrit:

The earliest base (prakrti) is Sanskrit. Then there is Prakrit. This [language, i.e. Telugu] ought to be considered as a distinctive modification (vikrti) of those two [languages, i.e. Sanskrit and Prakrit].

[ädya-prakrtih prakrtiśs cādye èșā tayōr bhavēd vikrtih (1.12)]

This sütra encapsulates the author's view on Telugu's relation to Sanskrit and Prakrit. The two languages are understood to be sources for Telugu. Indeed, the designation of Telugu as vikrti is ambiguous, and it is unclear if the author sees the language as derived from Sanskrit and Prakrit or as a distinct evolution of, that is nevertheless located in, the two languages. ${ }^{8}$

8 In an illuminating discussion on the subject, offering an etymological analysis of the term tadbhava, often translated as "derived from it (Sanskrit or, often in the case of regional words, Prakrit)," Kahrs subtly argues that the term tadbhava be understood as meaning "located" in Sanskrit (or Prakrit) and not "derived" from it. See Kahrs 1992, p. 226-237 for specific details of the argument. 
According to the author of the $\bar{A} \dot{S} C$, "established usage of speech is evident from general usage" (siddhir lokkād drśy $\bar{a}$ [1.6]), starkly revealing his stance that the regional language (albeit probably a literary register of it), widely used, qualifies it as siddha ("established") and, therefore, in the same domain as established languages like Sanskrit and Prakrit. By extension, "established" speech-forms of Sanskrit and Prakrit also have forms "derived from them" (sādhya or sādhyamāna), produced through phonological processes like sandhi or through the addition of various affixes. Hence, grammatical description of established and derived forms as performed in works like the $\bar{A} \bar{S} C$ underscores Telugu's proximity to Sanskrit and Prakrit. The use of the term siddha here hearkens back to the Kätantra grammar, which uses the term to describe the established inventory of sound-letters in Sanskrit (siddho varnasamāmnyāyah). Sütra 1.19 of the $\bar{A} S C$ elaborates on this term in the context of the nasalization, or anusvāra." "Unrefined speech" (apabhramsía), in contrast, would be considered "incorrect speech" (yat tv apabhramśah [1.10]). Building on sütra 1.9 (aniyamād grāmyam hi), where the author declares that speech that lacks rules is "unrefined" [lit. "rustic"], sūtra 1.10 implies that grāmya ("rustic") speech is equivalent to apabhramśa. The great Sanskrit grammarian Patañjali (second century BCE) explains apabhramśa (lit. "fallen away" or "corrupt") as ungrammatical usage in Sanskrit. Here, in the Telugu context, a connection is being made between grāmya and apaśabda ("an ungrammatical linguistic usage"). Essentially, therefore, grāmya is an apabhramśa of language that is refined and correct (samskārārtha).

\section{Analyzing the Technical Terms}

The table below summarizes most of the technical terms found in the opening chapter of the Andhraśabdacintāmani:

The first set (sütra 1.14) of technical terms speaks to delineating the Telugu alphabet. The $\bar{A} \dot{S} C$ follows the Prākrtaprakāśa, and by extension, the Kātantra in naming fifty varna or letters. The difference, of course, is that the fifty varna spoken of are not the same. ${ }^{10}$ The next sütra (1.18) defines the thirty-six varna of the Telugu alphabet with the Pāninian symbols for vowels $(a c)$ and consonants $(h a l)$. One noteworthy difference: whereas Pānini implicitly regards $e$ and $o$ as long vowels, the $\bar{A} \dot{S} C$ theorizes short $e$ and $o$ vowel counterparts to identify a perceived phonetic reality in Telugu. In employing

9 For a more elaborate discussion of the term siddha, refer below to the discussion on anusvāra, in the context of sütra 1.32 .

10 Vararuci's fifty varṇa for Sanskrit and Prakrit [dvidhāka ye cō'nusvārō visargah śōdaasvarāh sparśāntahstha-lōṣmānaśca catustrimíaddhalah smrtāh $]$ are comparable to the Kätantra's list, which does not mention anusvāra, visarga, or la. 


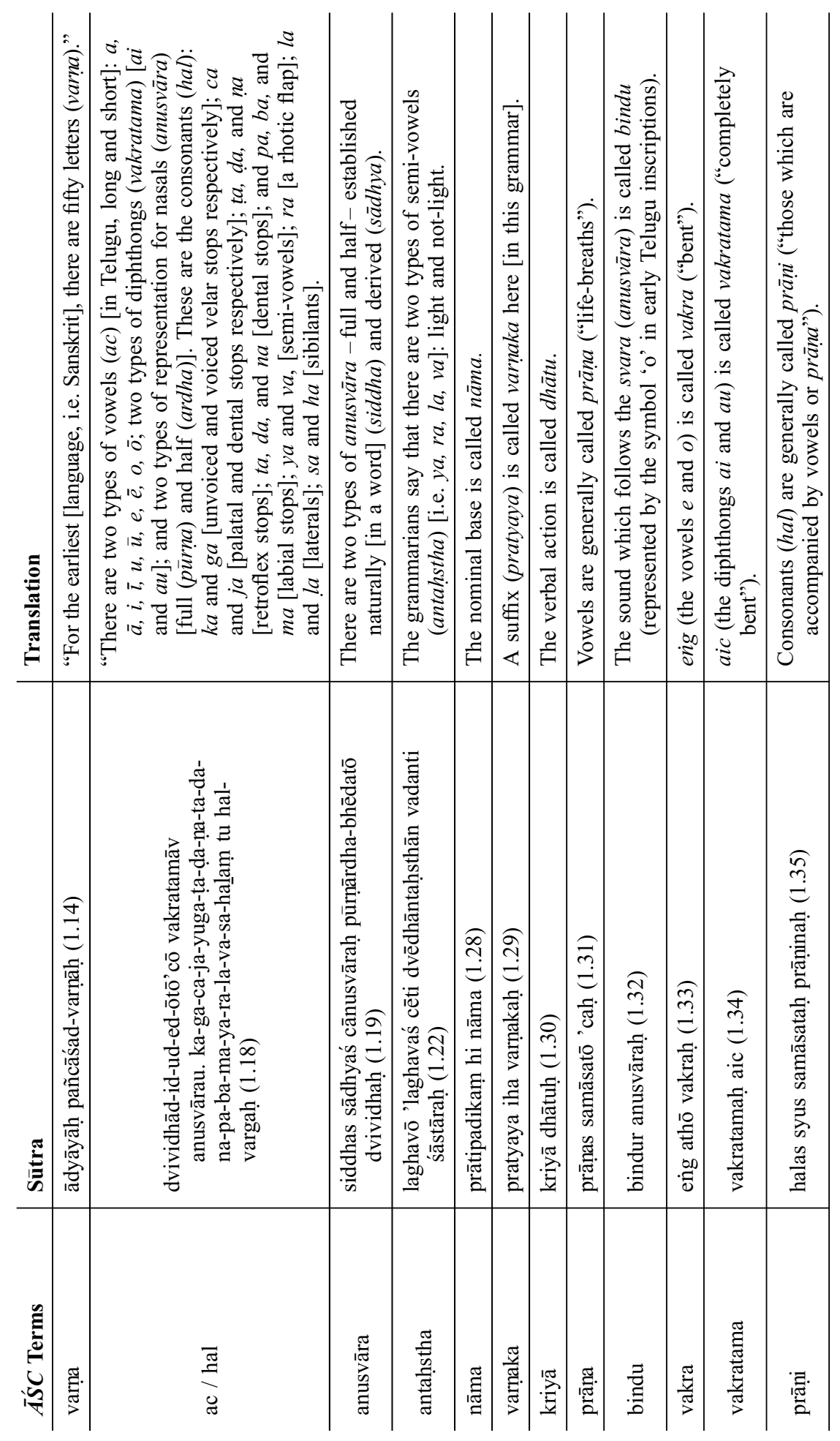


Appropriations and Innovations in Metalinguistic Terminology

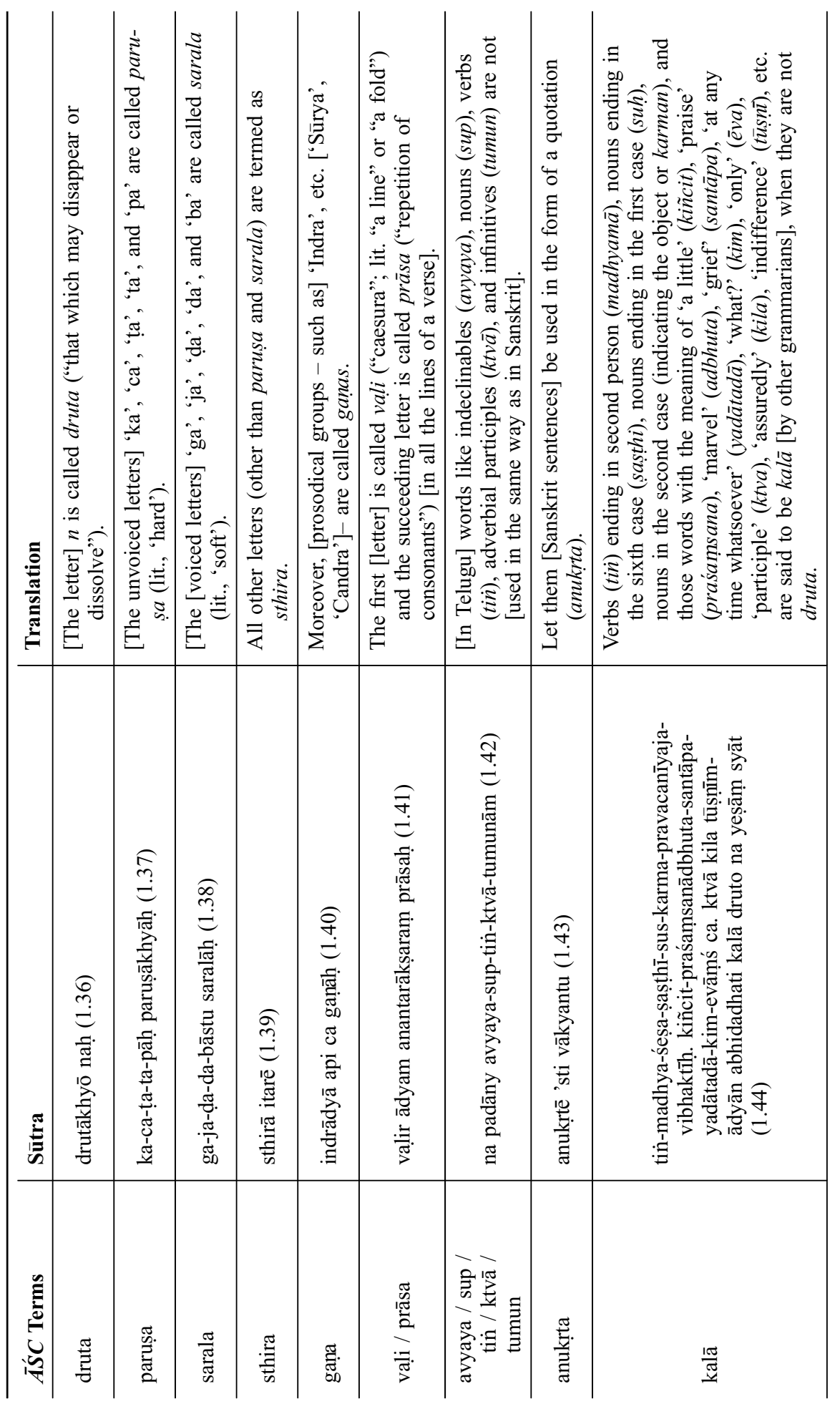




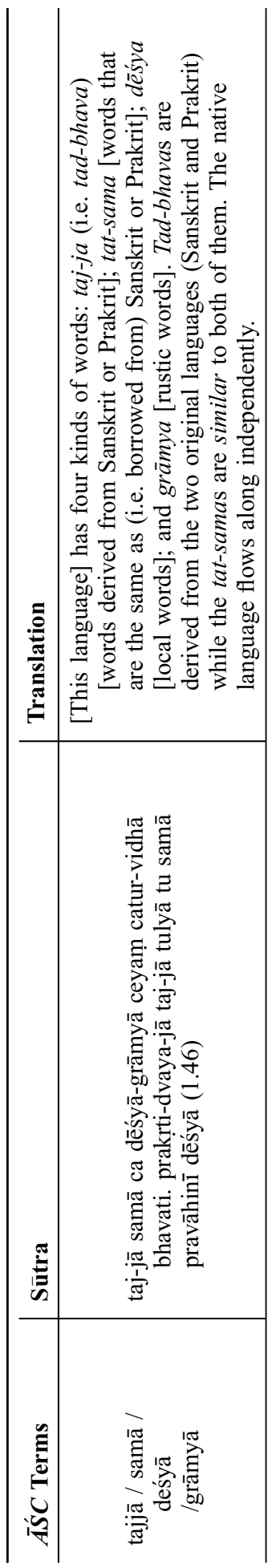


the Pāninian technical term it, therefore, the author of the $\bar{A} \bar{S} C$ synthesizes Pāninian technique with Kätantra theory, which does explain $e$ and $o$ as potentially long and short; thus, $a c$ (here, in the $\bar{A} \dot{S} C$ ) signifies that $i, u, e$ and $o$ are both long and short (dvividhā). In addition to using the Pāninian term for vowel, the $\bar{A} S C$ introduces a non-technical definition, in sütra 1.31: "Vowels are called prāna or "life-breaths." A connected definition for consonants occurs in sūtra 1.35: "Consonants are generally called prāṇi, "those possessing breath."11

The $\bar{A} \bar{S} C$ also implies another technical term for vowel, svara, by indicating the term anusvära (1.32), the "sound which follows the svara," which marks nasalization. This term is actually encountered first in 1.18 and 1.19 , where the author deploys the dual form anusvärau to signify that Telugu, on account of a distinct euphonic coalescence (sandhi) has two anusvāra - full (purna) and half $(\operatorname{ardha})$ - which take on different shapes in the orthography of the language. ${ }^{12}$ This marks an important aspect of the metalanguage of this grammar. What precipitates the use of this terminology is that, in Telugu, anusvära is theorized as naturally occurring in the word and thus established (siddha), or derived (sādhya) in that it comes resultant of sandhi. When there is sandhi (e.g. cen + tova $=$ cemdova), anusvāra, with its graphical mark, conditionally marks the nasal element. The anusvära primarily appears before consonantal stops. The fact that the graphical symbol of nasalization is here explicitly mentioned suggests the intersection of grammatical thought with writing in Telugu, something that is absent in the Sanskrit grammatical tradition. In fact, sütra 1.32 defines anusvāra as bindu ("dot"), the script marker for nasalization in the form of a dot, available in old Telugu inscriptions and later replaced by a zero marker.

Also potentially related to script, are the two technical terms - vakra ("bent") and vakratama ("completely bent") - respectively defined as names for the diphthongs $a i$ and $a u$ in sütras 1.33 and 1.34. The technical terms for the varna could point to their "curved" (vakra) form in the script. Or, as in the case of a similar usage in Tibetan grammar, the implication might be toward the curve made by the tongue within the vocal apparatus to produce the sound. Otherwise, there seems to be no need to differentiate these letters from the others. In some Telugu grammars, short $e$ and short $o$ are included but since here the author resorts to Pāninian terminology (eì), he cannot

11 This terminology of calling vowels prāna and consonants prāni is peculiar to Dravidian linguistics. Consonants form syllables only when accompanied with vowels (prāna or "lifebreaths"); otherwise, they are "lifeless," as it were.

12 The ardhānusvāra may or may not have had any phonetic value historically. In modern Telugu, it only appears in the script and is not read with nasalization. Even though it has no phonetic value now, it has historical value because in the ancient epics and in Old Telugu literature, the ardhānusvāra appears to be fixed (see Sundaram and Patel 2016, p. 13-15). 
represent short $e$ and short $o$ but only the long forms of these vowels. ${ }^{13}$ The term vakratama ("completely curved") refers phonetically to the Pāninian aic (ai and au). As vakra signifies the first level of vowel gradation Pānini calls guṇa (e and o), vakratama, apparently signifies second-level vowel gradation ( $v r d d h i$, i.e. $a i$ and $a u$ ). In describing the Tibetan grammar, Verhagen (2001, p. 49) describes the technical names given by Tibetan grammarians to capture the phonological system of Sanskrit, including the term bkug-pa ("bent" or "curved") for $i$, which is a "bent $a$ ". The diphthong $e$ is "stretched out" (bsgren-ba), while the diphthong $a i$ is "stretched out and bent" (bsgrens-te-bkug$p a)$. Verhagen writes that he has:

[...] not found parallels to this particular nomenclature in the Indic grammatical traditions. It can, in any case, not be related to the traditional classifications introduced in the varna-sütras within the major vyākarana traditions, or - as far as I can tell - to the earlier, Vedic Prātiśäkhya materials. The terms appear to be more or less impressionistic indications of the position and form assumed by the tongue (and other relevant parts of the oral cavity?) during the articulation of vowels. (ibid., p. 49)

Verhagen also notes that the Smra-sgo describes the phonology of Sanskrit vowels "in terms of the visual form of graphs" (ibid.). Again, if one follows the theory that the technical language is pointing to a grapheme and not the peculiar curvature of the tongue to produce the sound, then the apparent graphical representation of Telugu through the Sanskrit technical terminology would be a novel contribution to Indian linguistics. Unlike other non-Indic linguistic contexts, where the overlay of the graphical representation of one language onto another may lead to distortion (such as applying the Latin alphabet to African languages, for instance), the problem seems not relevant here, as Sanskrit and Prakrit grammars are not explicitly concerned with graphical representation.

In domains shared between Telugu and Sanskrit/Prakrit, on the other hand, the metalinguistic terms are identical, as in sütra 1.42, where the technical Pāninian symbol clusters sup (nouns), tin (verbs), ktvā (adverbial particles), and tumun (infinitives) are imported wholesale from Sanskrit and preserved alongside the specialized word avyaya (indeclinable words). While the actual Telugu nominal, verbal, and participial suffixes obviously differ from the Sanskrit in form, the $\bar{A} S C$ organizes Telugu suffixes using Pāninian symbol clusters as technical terms to suggest conceptual and operational similarities with Pānini’s scheme for describing

13 Pānini does not make a two-fold delineation (dvividhā) for long and short vowels. For Pāninini, $e$ and $o$ are long vowels; they have no short counterparts. In this sütra, the author takes both from Pānini (in the use of the it-samjiña $)$ and the Kätantra. So, $i, u$, and $e$ (it, ut, et) are explained as both long and short. There is dvividha for $i t$ and $u t$ but there is no way to explain $e$ and $o$, as both long and short. Thus the author gives et and ot, signifying that dvividha applies to both. He takes Pānini's technical term $(a c)$ but redeploys it to describe what happens in Telugu. 
suffixes. The author of the $\bar{A} \bar{S} C$ then goes on to exemplify this connection. For instance, Pāninini's term tumun-anta ("ending in tum[un]") signifies an affix called tum attached to the end of a verb-stem to form the infinitive, as in gantum ("to go") and pathitum ("to read"). The infinitive is called the tumun-anta in Telugu as well, but the affix that is actually attached is $k u$ as in povutaku ("to go") and caduvutaku ("to read"). This suggests that the logic of the grammar places the meaning associated with "ending in tumun" (tumun-anta) as an infinitive form to transcend the etymological meaning of "ending in tumun" as an infinitive form that ends in the suffix tum. The situation in sütra 1.43 is reversed, where the term anukrta (literally, "imitation" or "following" in Sanskrit) is used to indicate that quotations from Sanskrit sources are treated the same way in Telugu. The peculiar feature here is that a quotation, in Telugu, is followed by the word $a n u$, which corresponds to iti ("thus") in Sanskrit, used ubiquitously to mark quotation. For example, in Sanskrit, direct discourse followed by iti rāmāvadat ("thus said Rāma") corresponds to the Telugu form ane rāma ("said Rāma"), where ane is the past-tense form of anu. While the use of the word "anukrta" is not explicitly being tied to the quotative marker $a n u$, the author is suggesting that the Telugu employment of anu to mark quotation imitates the usage of $i t i$ in Sanskrit. A glaring difference between the two markers is that while it $i$ is a particle that does not conjugate along with the changing tense of the verb it accompanies, the Telugu anu does undergo change according to its accompanying verbal form.

The rest of the technical language in Chapter 1 of the $\bar{A} S C$ consists of a mix of pre-Pāninian, and completely new phonological metalanguage. Sütra 1.28 juxtaposes a Pāninian usage with an earlier term for a nominal base: "In Telugu, prātipadika is also called nāma." Sütra 1.30 defines a "verbal action" as a dhātu (root). Sütra 1.29 introduces a new term, varnaka, in the sense of a suffix (pratyaya) to indicate the common Telugu endings to nominal items (such as firstcase endings like $d u, m u, v u$, and $l u$ ). The next set of terms is, to my knowledge, unavailable outside of this grammar:

1.36: druta ("disappearing," "dissolved")

1.37: paruṣa ("hard")

1.38: sarala ("soft")

1.39: sthira ("stable")

1.44: kalā ("portion")

The term druta indicates the "disappearance" or "dissolution" of the letter $n$ or $n a$ or $n u$ at the end of words. There are three types of $n$ in Telugu: $n u, n a$, and the $n$ that becomes an anusvāra nasal. This last $n$ optionally disappears in Telugu. Unvoiced stops are called parușa ("hard") in Telugu. There are other terms for this feature in Sanskrit that translate to "unaspirated" (alpa-prāna) and "unvoiced" 
(aghōsa). The term paruṣa, however, applies to the first letters in each consonantal class (varga). In early Prakrit grammars, each are just named according to the varga they inhabit as, for example, in the Prākrtānusāsana of Puruṣottama and in Ravana's (Lañkeśvara's) Prākṛtakāmadhēnu. Only the Āndhraśabdacintāmaṇi gives this particular term. By contrast, voiced stops are called sarala ("soft") in Telugu. Cinnayasūri, mentioned earlier as the author of the influential 1855 Telugu grammar Bālavyākaranamu, translates this and the previous sütra verbatim, using the same terminology. ${ }^{14}$ All other letters (aspirated, nasals, semi-vowels, and sibilants) are called sthira, as they remain "stable" and unchanged. The author of this grammar may be drawing from the tradition of the R R Prātiśăkhya, a pre-Pān inian work (c. 600 BCE?) that deals with the phonetics of the Rgveda. Rk Prātiśákhya 13.9-11 defines a consonantal stop as not fixed (sprsțtam asthitam), and therefore, coming and going quickly. As parușa and sarala letters are understood as "unstable" (asthira), on account of their transformation in certain phonetic and semantic environments, the logic of this term sthira may stem from the usage found in early texts on phonetics, such as the R R Prātiśäkhya. A final technical term - peculiar in its scope and distinctively Telugu - is $\boldsymbol{k a l a}$ ("portion") that, according to sütra 1.44, denotes: a) all verbs (tiin) ending in second person (madhyamāa); b) all nouns ending in the sixth case (sasthi), the first case (suh), the second case (indicating the object); and c) those words with the meaning of "a little" (kiñcit), "praise" (praśamısana), "marvel" (adbhuta), "grief" (santāpa), "at any time

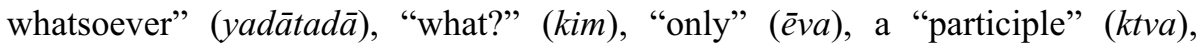

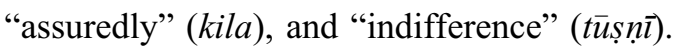

All "other" words (anyē), according to sütra 1.45, i.e. those that are not kalāa, are subject to being druta. The reason for the technical metalinguistic distinction here, between words that undergo druta (loss of the $n, n a$, or $n u$ ) and words that do not $(k a l \bar{a})$, is not clear. One may surmise that the distinction stems from an anxiety around the loss or "dissolution" (druta) of the $n, n a$, or $n u$, which occurs either as an augment or, surprisingly, even as an indeclinable (avyaya) component of words that end in $n$. As this phenomenon is unique to the $n$, and not applicable to any other augment (ägama) or word-final consonant, the terminological distinction between druta and kalä might exist to mark this special loss of the $n$. The term kala (which is tentatively translated here as "portion") marks those words (or, perhaps, a portion of those words) that especially do not undergo this peculiar druta process. Kalāa, as defined in sütra 1.44, does not encompass all non-druta words, however, so it remains hazy why only these forms have been selected here. The other chapters of the $\bar{A} S C$ refer to this distinction in giving examples of druta, but the explicit division between words that are druta and kalä occurs only in this opening chapter. 
An important set of new terms in the $\bar{A} \dot{S} C$ 's first chapter refers to prosody. The Telugu metrical gana system is different from the one found in Sanskrit or Prakrit and, therefore, occasions the need for terminological intervention. In Sanskrit, there are no names for the fixed metrical clusters (gana), outside of labels of sets of letters or numbers of syllables. For example, ya-gana signifies a three-syllable cluster of lightheavy-heavy syllables, whereas ma-gana signifies three consecutive heavy syllables, ta-gana would be heavy-heavy-light, and so on; similarly ekāksara-gana would signify a cluster with only one (eka) syllable, dvyaksara-gana with two (dvi) syllables, and tryakșara-gana with three (tri) syllables. In Prakrit, names reflect the number of mora (mātra) in each class. According to sütra 1.40 of the $\bar{A} \dot{S} C$, however, names for gaṇa are given, such as indra, sürya, and candra respectively signifying short, moderate, and long units of time wherein specific syllables or morae are recited. In addition to naming the groups, the $\bar{A} \dot{S} C$ also provides some distinctive technical terms to describe the specificities of Telugu prosody. For example, it introduces the term vali (a distinctive form of the Sanskrit yati ("caesura") as well as prāsa, where the second letter in each of the four $p \bar{a} d a$ s is identical. Vali, which might indicate a "line" or "fold" that serves as a differentiating mark is a type of caesura distinct from what is meant in Sanskrit prosody. According to sütra 1.41, the first letter (or a letter related to the first letter of the same class) is called vali (valir ädyam), which is repeated at some prescribed point. Thus, in lieu of a pause (yati) found in Sanskrit, the first letter is repeated further on in the pada or line, largely for aesthetic reasons (perhaps to make it more pleasing). Similarly, the second letter in each of the four lines of a Telugu verse is called prāsa, a characteristic feature of Telugu metrical compositions. Telugu prāsa is not to be confused with the technical term for the Sanskrit trope of alliteration (anuprāsa). Prāsa is not a sound-trope (śabdālañkāra), as in Sanskrit poetics, but rather its creative function in Telugu poetic contexts comes from its restrictive aspect. Vali is mandatory in all Telugu verse while prāsa is virtually mandatory in all verse.

The penultimate $s \bar{u} t r a$ (1.46) of this chapter uses metalanguage seen elsewhere in Sanskrit and Prakrit grammars to describe the nature of shared lexicons between Telugu and Sanskrit/Prakrit: tajja (words derived from Sanskrit or Prakrit words), ${ }^{15}$ tatsama (words that are identical with Sanskrit and Prakrit words), deśya (local Telugu words), and grāmya (rustic usages). ${ }^{16}$ While derived and identical words

15 While admitting that the only extant usage he can find for the term tajja (lit. "born of it [i.e., Sanskrit]) comes from the twelfth-century Jain author Vāgbhața's poetics text Vāgbhața lankāra, Kahrs accepts the term as a synonym for the more common tadbhava ("located in it"), which refers to words that are not identical with corresponding Sanskrit words but rather born from them. See Kahrs 1992, p. 230.

16 Tātambhaț̣u's fifteenth-century Kavicintāmaṇi (or, alternatively, Kavilōkacintāmaṇi, Sukavicintāmaṇi, Kāvyānuśāsanamu, and Kävyacintāmaṇi) acknowledges only the first three types of Telugu words, subsuming grāmya into deśya. 
have as their substratum (prakrti) the two classical languages, the "native language", the author cryptically concludes, "flows along independently" (pravāhinī deśya).

\section{Conclusions}

On the surface, it is not particularly startling that the Andhraśabdacintāmani $i$ would appropriate and innovate upon its Sanskrit (and Prakrit) predecessors. First, there is the singular fact, demonstrated by the $\bar{A} \dot{S} C$, that Telugu and Sanskrit fundamentally share morpho-phonetic, structural, and lexical qualities that naturally draw them together. Second, relying on a Sanskrit, Prakrit, and Pali tradition that has already worked out over centuries a technology of linguistic description, celebrated for its brevity, comprehensiveness, and rule-ordering logic seems commonsensical, over and above inventing a wholly novel descriptive system. The actual exercise of grafting Pāninian techniques developed for describing Sanskrit onto Telugu, however, poses various challenges, as shown above. One intriguing aspect about a text like the $\bar{A} S C$, however, is the ways in which inherited techniques of linguistic description integrate with ingenious innovations necessary to explain distinctive features of Telugu phonology, orthography, and in a startling turn, prosody, while also making pointed comments about the special identity of the Telugu language. In this regard, the author confidently asserts in sütra 1.5 that people

whose minds are passionate toward rasa (the emotional aspect of art and literature) love their own native place, its fashions, and its language. In this world, leaving aside other kinds of poetry (i.e. Sanskrit and Prakrit), they hold in high regards their own poetry.

While acknowledging how special Telugu is and how it requires its own analysis, the author clearly sees the advantages of extending the metalinguistic terminology and methodology from Sanskrit to Telugu. In cases where inherited definitions cannot adequately categorize linguistic units or features, the Telugu grammar either provides a criterion of identification in the form of discrete sütras unfamiliar to Sanskrit and Prakrit grammar or creates a wholly new definition by either inventing a term or by innovating a sütra.

One obvious field of analysis from which the $\bar{A} S C$ profits concerns Sanskrit's comprehensive objectification of phonological processes within words and across word boundaries and the metalanguage that accompanies it. As the author of the $\bar{A} \dot{S} C$ intends to standardize a literary Telugu from what is hitherto a standardized spoken Telugu drawing together disparate but related dialects, the appropriations significantly assist the process. Metalinguistic terminology certainly heightens, if not catalyzes, the move toward literary standardization, as the terminology touches on every aspect of literariness, including poetics and orthography. As seen above, 
the grammar's author seems to reflect on orthography, thus signaling an innovation necessary for Telugu grammarians in a way that it was not necessary for Sanskrit and Prakrit grammarians. Similarly, the $\bar{A} S C$ accomplishes the description of Telugu phonological features distinctive from Sanskrit and Prakrit as well. The concept of ardhannusvāra, for instance, is described in the $\bar{A} \bar{S} C$ using the Sanskrit analytic to explain certain letters (like aspirates) that are in one language but not the other. The terminology has to follow a methodology to demonstrate where one language's feature deviate from another. Thus, the introduction of terms like druta, parusa, sarala, bindu, and ardhabindu must have some special purpose for the Telugu grammarian.

In speculating on why such a work - which seems so heavily skewed toward understanding Telugu through Sanskrit - one may proceed in several directions. First, in assuming that the audiences of this grammar knew Sanskrit, one may surmise that the simple goal of the $\bar{A} \bar{S} C$ is to make known the structure of the Telugu language to native speakers. Another possibility raises the historical reality of multilingual courts and scholastic contexts, where scholars of Kannada and Tamil, perhaps, would be interacting with Telugu speakers. In this context, shared knowledge of Sanskrit and Sanskrit grammar, especially, could be a valuable instrument to accomplish the understanding of a foreign language in familiar terms; in other words, metalinguistic awareness would be a stepping-stone toward bilingual competency. Some have attributed this logic to the Kâtantra grammar, perhaps designed for Prakrit speakers to learn Sanskrit, or the Rüpāvatāram of tenth-century Buddhist grammarian Dharmakirti, which is the first of the so-called prakriya $\bar{a}$ works that reorders Pānini's sūtras topically, presumably for ease of learning the language. Similar might be the case of the eleventh-century Tamil Viracōliyam grammar, which has been described, at least in one scholar's opinion, as a "“contrastive-transfer grammar' attempting to teach a second language (Tamil) through the application and transfer of categories from the student's first language (Sanskrit)" ${ }^{17}$ Another describes some of the Viracōliyam's uniqueness in terms of its complex mediating function, "theorizing Tamil grammar and poetics through lenses first developed for Sanskrit" (Monius 2013, p. 106). Monius sees the act as largely emblematic of processes of vernacularization across South Asia during the medieval period (Monius 2013, p. 115).

Another possibility suggests itself in the $\bar{A} \bar{S} C$ itself: that it seeks to elevate Telugu language to the heights achieved by prestigious classical languages and, therefore, by extension, assumes its prestige as well. "Poetry is for universal welfare," the first sūtra (1.1) asserts, and "poetry without blemishes consists of a

17 Anne Monius (2013, p. 106, fn. 12) attributes Canmukam Pị̣lai ("Vìracōliyam: The Earliest Contrastive-Transfer Grammar in Tamil?") with this suggestion. 
combination of speech and meaning" (1.2). Then the author explains that poetry "leads to rasa" (1.3) and that the goal of poets is to "achieve rasa that is brought about in an appropriate way" (1.4). Finally, the author of the $\bar{A} S C$ makes his strongest statements: poetry is not of one kind nor does it belong to the domain of any single language but only that people "hold in high regard their own poetry" (1.5).

While Sanskrit and Prakrit poetry - never connected to a specific region - is respected and valued, the author explains that it is natural for people to respond to literature that speaks to their place and their local culture. By extension, one may correlate that just as Telugu poetry intimately relates to Sanskrit and Prakrit poetry in shared inheritance of literary topoi and cultural themes, so too should its grammar draw from its inheritance while still identifying those aspects that make it linguistically (phonologically and morphologically) distinctive. To strike a balance in this perceived continuum, however, the Telugu has to destabilize Sanskrit and Prakrit as sole domains of literary expression. The emergence of metalinguistic technologies, whether through appropriation or innovation, often births new grammars that, in turn, simultaneously subject the language to undergo grammaticization and literarization. The $\bar{A} \bar{S} C$ 's descriptions of Telugu through Sanskrit reveal the language to be both like and unlike Sanskrit and, therefore, as able to function in both a classical and vernacular space.

Significantly, however, the $\bar{A} \hat{S} C$ seems to be aware that, while the techniques and presuppositions of Sanskrit and Prakrit grammatical analysis condition its own foundational project, it is by no means necessary that these techniques overwhelm or misrepresent the true of object of the work, which is to describe how Telugu's features operate. The $\bar{A} \dot{S} C$, again, may superficially appear to be offering Sanskrit and Prakrit-based grammatical prescriptions for understanding how Telugu linguistic forms operate, but the plasticity of the sütras in their formulation and the additions made to accommodate distinctive features of the Telugu seem to quell any suspicions that the Telugu's distinctiveness is being compromised to validate non-Telugu grammatical prescriptions.

\section{BIBLIOGRAPHIE}

Ananthanarayana, H.S., 2017. "Pāṇinian Model for Describing Telugu in Bālavyākaran amu", International Journal of Dravidian Linguistics Vol. 46 No. 1, 70-85.

Andronov, Mikhail S., 2003. A Comparative Grammar of the Dravidian Languages, Wiesbaden, Otto Harrassowitz Verlag.

Aussant, Émilie, 2012. "Pāṇinian features of the oldest known Malayālam description", Cardona, George, Aklujkar, Ashok and Ogawa, Hideyo (eds.), Studies in Sanskrit Grammars, Proceedings of the Vyākarana Section of the $14^{\text {th }}$ World Sanskrit Conference, New Delhi, D.K. Printworld, 87-101.

Burnell, Arthur C., 1976 [1875]. On the Aindra School of Sanskrit Grammarians, Varanasi, Bharat-Bharati. 
Kahrs, Eivind, 1992. "What is a Tadbhava Word", Indo-Iranian Journal 35, 225-249.

Monius, Anne, 2013. "'Sanskrit is the Mother of All Tamil Words': Further Thoughts on the Viracoliyam and its Commentary", Buddhism Among Tamils, Part 3, Uppsala, Acta Universitatis Upsaliensis, Historia Religionum 32, 103-129.

Sundaram, Rallapalli V.S. and Patel, Deven M., 2016. Āndhraśabdacintāmaṇi: A Grammar of the Telugu Language in Sanskrit (Edition and Translation with Notes and Introduction), Mysore, Central Institute of Indian Languages.

Verhagen, Pieter C., 2001. A History of Sanskrit Grammatical Literature in Tibet Volume 2, Leiden, Brill. 